Available online on 15.01 .2019 at http://jddtonline.info
Journal of Drug Delivery and Therapeutics
Open Access to Pharmaceutical and Medical Research
(c)11-18, publisher and licensee JDDT, This is an Open Access article which permits unrestricted
non-commercial use, provided the original work is properly cited

Open $\odot$ Access

Research Article

\title{
Evaluation of anti-microbial and anti-haemolytic activity of edible basidiomycetes mushroom fungi
}

\author{
Madhanraj R', Ravi Kumar $K^{1}$, Maya $\mathbf{M ~ R}^{1}$, Ramanaiah Illuri' ${ }^{1}$, Venkatakrishna $\mathrm{K}^{1}$, Rameshkumar $\mathrm{K}^{2}$, \\ Veeramanikandan $\mathbf{V}^{3}$, Eyini $\mathbf{M}^{4}$, Balaji $\mathbf{P}^{1 *}$ \\ ${ }^{1} P G$ and Research Centre in Biotechnology, MGR College, Hosur, Tamilnadu, India, \\ ${ }^{2} P G$ and Research Department of Zoology, Vivekananda College, Madurai, Tamilnadu, India, \\ ${ }^{3} P G$ and Research Centre in Microbiology, MGR College, Hosur, Tamilnadu, India, \\ ${ }^{4}$ Centre for Research and PG studies in Botany, Thiagarajar College, Madurai, Tamilnadu, India.
}

\begin{abstract}
Mushrooms are used for a variety of biotechnological applications, particularly for the production of food, enzymes, dietary supplements, pharmaceutical compounds, feed supplements. Basidiomycetes mushroom fungi have been known for their nutritional values they can be considered as functional foods which can provide health benefits beyond the traditional nutrients. Mushroom represents a major and untapped source of potent new pharmaceutical products. A wide range of activities including antitumour, cardiovascular and antimicrobial are reported in mushrooms. In developing countries like India mushroom progress is a boon in the field of food, medicine, and in generating employment. The alternative systems of medicine utilize the curative properties of mushrooms. They are also known to possess promising antioxidative, cardiovascular, hypercholesterolemia, antimicrobial, hepato-protective and anticancer effects. The present study aimed to evaluate antimicrobial and antihaemolytic activities of various extracts of Basidiomycetes mushroom fungi. Different Basidiomycetes mushroom fungi extracts (Hot water, Acetone and Hexane) were tested for antimicrobial and antihaemolytic activities. Among these different extracts of Basidiomycetes mushroom fungi the hexane extract of Pleurotus pulmonarius showed potential antimicrobial and antihaemolytic activity. The results of this study suggest the possibility of using Basidiomycetes mushroom fungi as natural sources for the pharmaceutical industry and could act as safe and cost-effective with potential biological activities. These findings encourage studying these fungal strains further for their potential biological applications.
\end{abstract}

Keywords: Basidiomycetes, Anti-microbial, Anti-haemolytic, Pharmaceutical

Article Info: Received 20 Nov 2018; Review Completed 29 Dec 2018; $\quad$ Accepted 02 Jan 2019; Available online 15 Jan 2019

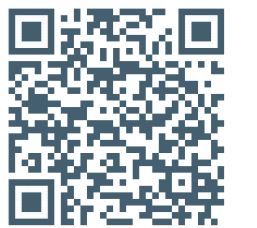

Cite this article as:

Madhanraj R, Ravi Kumar K, Maya MR, Ramanaiah I, Venkatakrishna K, Rameshkumar K, Veeramanikandan V, Eyini M, Balaji P, Evaluation of anti-microbial and anti-haemolytic activity of edible basidiomycetes mushroom fungi, Journal of Drug Delivery and Therapeutics. 2019; 9(1):132-135 DOI: http://dx.doi.org/10.22270/jddt.v9i1.2277

Dr. P. Balaji, PG and Research Centre in Biotechnology, MGR College, Hosur - 635130, Tamilnadu, India.

\section{INTRODUCTION}

Mushrooms have become attractive as a functional food and as a source for the development of drugs and nutraceuticals responsible with their antioxidant, antitumorand antimicrobial properties $^{1,2}$. Besides their pharmacological features, mushrooms are becoming more important in our diet due to their nutritional value, related to high protein and low fat / energy contents ${ }^{3}$. Trametes versicolor (L.) Lioyd has been considered among the 25 major medicinal macrofungi worldwide ${ }^{4}$, mainly due to its traditional usage. In recent years Basidiomycetes and other higher fungi including some recognized medicinal mushrooms have been recognized medicinal mushrooms have been re-investigated as sources of novel antibiotics mainly as a result of increasing difficulty and the cost of isolating novel bioactive compounds from the Actinomycetes and Streptomycetes ${ }^{5}$.
A variety of mushrooms have been used traditionally for the maintenance of health and for prevention and treatment of diseases such as cancer, inflammation, viral diseases, hypercholesterolemia, blood platelet aggregation and hypertension 6-10. Medical mycology is as old as traditional uses of mushrooms. They have been used in medicine since the Neolithic and Paleolithic eras ${ }^{11}$.

The present research possesses an idea about the antibiotic activity of some of the important edible Basidiomycetes mushroom fungi. Several edible mushrooms have traditionally been used in China and other countries like Japan, Korea, USA etc. An old Chinese proverb regarding mushrooms states that "medicine and food have a common origin". At present there are at least 270 species of mushrooms that are known to have various therapeutic properties like antitumor, anticancer, anti-inflammatory, antithrombotic, antidiabetic, antifibrotic, antimicrobial, antiviral, anti-hypersensitive, cholesterol reducing, CODEN (USA): JDDTAO 
hypogloycemic etc. A few are responsible for lowering of blood pressure.

Pleurotus species have high medicinal value. Compounds extracted from these mushrooms exhibit activity against various chronic diseases including hypertension, hypercholesterolemia ${ }^{12-14}$. The medicinal beneficial effects of Pleurotus species were discovered independently in different countries. Oyster mushrooms (Pleurotus species) are excellently edible and nutritious, rank among one of the most widely cultivated mushrooms in the world ${ }^{15}$.

The screening of mushrooms from different ecological and geographical regions of India is still required to identify, isolate, design, develop, modify or to prepare new pharmacologically active compounds from wild mushrooms. Considering the immense importance of mushrooms as a source of food as well as herbal medicines, the present study is dealt with a recent insight on the pharmaceutical potential of some edible Basidiomycetes mushroom fungi.

\section{MATERIALS AND METHODS}

\section{Basidiomycetes Fungi}

The pure cultures of basidiomycetes mushroom fungal strains used in the present study were Pleurotus citrinopileatus, Pleurotus eous, Pleurotus cystidiosis, Pleurotus ostreatus, Pleurotus eryngii, Pleuoruts flabellatus, Pleurotus florida, Pleurotus pulmonarius and Schizophyllum commune. Pure cultures were maintained in PG and Research Centre in Biotechnology, M.G.R. College, Hosur.

\section{Storage and maintenance of Basidiomycetes fungi}

Pure cultures of fungi were stored at $10^{\circ} \mathrm{C}$. Sub-culturing was performed every month to ensure that the organisms remained viable. The mycelial agar plugs $(7 \mathrm{~mm})$ from the stock cultures were aseptically transferred to fresh Potato Dextrose Agar medium and then incubated at room temperature $\left(28 \pm 2^{\circ} \mathrm{C}\right)$ until confluent growth was achieved.

\section{Test organisms}

The bacterial strains used throughout this study as test organisms for investigating the anti-microbial activity of the selected mushroom fungi were Bacillus sp., Proteus sp., and Staphylococcus aureus. All the bacterial strains were grown in nutrient broth aerobically in Erlenmeyer flasks and were stored as nutrient agar slants at $4^{\circ} \mathrm{C}$.

\section{Anti-microbial activity}

Screening for antimicrobial activity against microorganisms including bacteria such as Bacillus sp., Proteus sp. and Staphylococcus aureus was carried out to determine whether the mushroom extracts possessed any biological activity. Antimicrobial activity was measured by agar well diffusion assay. Fresh cultures of test bacterial strains were grown overnight in nutrient broth to get $10^{5} \mathrm{CFU} / \mathrm{ml}$. $0.1 \mathrm{ml}$ of each bacterial suspension was used to inoculate individual petridish containing nutrient agar medium with a sterile non-toxic cotton swab on a wooden applicator. Eight millimeter diameter 5 wells were punched in the agar plates. Aliquots $(25 \mu \mathrm{l}, 50 \mu \mathrm{l}, 75 \mu \mathrm{l}, 100 \mu \mathrm{l}$ and $125 \mu \mathrm{l})$ of the various mycelial extracts were used to fill the wells. The plates were incubated at $28 \pm 2{ }^{\circ} \mathrm{C}$ overnight. Anti-bacterial activity was recorded by measuring the zone of growth inhibition around the well.

\section{Anti-haemolytic activity}

By centrifugation the erythrocytes from cow blood were separated and washed with phosphate buffer ( $\mathrm{pH}$ 7.4). With phosphate buffered saline the erythrocytes were then diluted to give $4 \%$ suspension. To $2 \mathrm{ml}$ of the erythrocyte suspension $500 \mu \mathrm{g}$ of extract $/ \mathrm{ml}$ of saline buffer were added and with saline buffer the volume was made up to $5 \mathrm{ml}$. At room temperature the mixture was incubated for $5 \mathrm{~min}$ and in saline buffer $0.5 \mathrm{ml}$ of $\mathrm{H}_{2} \mathrm{O}_{2}$ solution was added to induce the oxidative degradation of the membrane lipids. The concentration of $\mathrm{H}_{2} \mathrm{O}_{2}$ in the reaction mixture was adjusted to bring about $90 \%$ haemolysis of blood cells after $240 \mathrm{~min}$. After incubation the reaction mixture was centrifuged at $1500 \mathrm{rpm}$ for $10 \mathrm{~min}$ and the extend of haemolysis was determined by measuring the absorbance at $540 \mathrm{~nm}$ corresponding to haemoglobin liberation. The percentage of haemolysis was calculated by using the formula $\left.\left[\left(\mathrm{A}_{0}-\mathrm{A}_{1}\right) / \mathrm{A}_{0}\right)\right]$ $\mathrm{X} 100$, where $\mathrm{A}_{0}$ is the absorbance of the control (reaction mixture without extract) and $A_{1}$ is the absorbance of the extract/ standard.

\section{RESULT AND DISCUSSION}

Screening for antibacterial activity against microorganisms including bacteria such as Bacillus sp., Proteus sp. and Staphylococcus aureus was carried out to determine whether the extracts of Basidiomycetes mushroom fungi shows any biological activity.

Table 1: The antimicrobial activity of $P$. citrinopileatus, $P$. eous and $P$. cystidiosis

\begin{tabular}{|c|c|c|c|c|c|c|c|c|c|c|}
\hline \multirow{3}{*}{ Test organism } & \multirow{3}{*}{ Concentration $(\mu \mathrm{l})$} & \multicolumn{9}{|c|}{ Zone of inhibition diameter $(\mathrm{cm})$} \\
\hline & & \multicolumn{3}{|c|}{ Pleurotus citrinopileatus } & \multicolumn{3}{|c|}{ Pleurotus eous } & \multicolumn{3}{|c|}{ Pleurotus cystidiosis } \\
\hline & & Acetone & Hexane & $\begin{array}{c}\text { Hot } \\
\text { water }\end{array}$ & Acetone & Hexane & $\begin{array}{c}\text { Hot } \\
\text { water }\end{array}$ & Acetone & Hexane & $\begin{array}{c}\text { Hot } \\
\text { water }\end{array}$ \\
\hline \multirow{5}{*}{ Bacillus sp. } & 25 & 1.2 & 1.5 & 0.6 & 1.3 & 1.0 & 0.6 & 0.9 & 1.0 & 0.8 \\
\hline & 50 & 1.5 & 1.8 & 0.8 & 1.4 & 1.1 & 0.8 & 1.0 & 1.5 & 1.1 \\
\hline & 75 & 2.1 & 2.4 & 1.0 & 1.7 & 1.2 & 1.1 & 1.1 & 1.7 & 1.3 \\
\hline & 100 & 1.9 & 2.1 & 1.3 & 1.9 & 1.3 & 1.3 & 1.3 & 1.6 & 1.5 \\
\hline & 125 & 1.8 & 2.3 & 1.2 & 1.9 & 1.1 & 1.2 & 1.7 & 1.8 & 1.8 \\
\hline \multirow{5}{*}{ Proteus sp. } & 25 & 0.8 & 1.2 & 0.9 & 1.1 & 1.0 & 0.8 & 1.0 & 1.0 & 1.1 \\
\hline & 50 & 0.6 & 1.5 & 0.6 & 1.2 & 0.8 & 0.9 & 1.1 & 1.2 & 1.2 \\
\hline & 75 & 0.8 & 1.7 & 0.9 & 1.5 & 0.9 & 1.0 & 1.2 & 1.8 & 1.4 \\
\hline & 100 & 1.1 & 1.6 & 1.0 & 1.6 & 1.1 & 1.3 & 1.5 & 2.2 & 1.8 \\
\hline & 125 & 1.2 & 1.7 & 1.3 & 1.8 & 1.5 & 1.4 & 1.8 & 2.3 & 1.9 \\
\hline \multirow{5}{*}{$\begin{array}{c}\text { Staphylococcus } \\
\text { aureus }\end{array}$} & 25 & 1.0 & 1.5 & 0.4 & 1.1 & 1.1 & 0.7 & 1.0 & 1.2 & 1.0 \\
\hline & 50 & 1.1 & 1.7 & 0.8 & 1.3 & 1.5 & 1.0 & 1.3 & 1.4 & 1.1 \\
\hline & 75 & 1.3 & 1.8 & 1.9 & 1.6 & 1.6 & 1.4 & 1.4 & 1.6 & 1.6 \\
\hline & 100 & 1.9 & 2.1 & 1.1 & 1.8 & 1.6 & 1.4 & 1.5 & 1.7 & 1.8 \\
\hline & 125 & 1.9 & 1.9 & 1.2 & 1.7 & 1.8 & 1.6 & 1.4 & 1.7 & 1.7 \\
\hline
\end{tabular}


The result of the evaluation revealed that hexane extract of Pleurotus pulmonarius showed the significant activity, acetone extract of Schizophyllum commune showed the moderate activity and hexane extract of Pleurotus eryngii showed the least activity.

Table 2: The antimicrobial activity of $P$. ostreatus, $P$. eryngii and $P$. flabellatus

\begin{tabular}{|c|c|c|c|c|c|c|c|c|c|c|}
\hline \multirow[t]{3}{*}{ Test organism } & \multirow[t]{3}{*}{ Concentration $(\mu \mathrm{l})$} & \multicolumn{9}{|c|}{ Zone of inhibition diameter $(\mathrm{cm})$} \\
\hline & & \multicolumn{3}{|c|}{ Pleurotus ostreatus } & \multicolumn{3}{|c|}{ Pleurotus eryngii } & \multicolumn{3}{|c|}{ Pleuoruts flabellatus } \\
\hline & & Acetone & Hexane & $\begin{array}{c}\text { Hot } \\
\text { water }\end{array}$ & Acetone & Hexane & $\begin{array}{c}\text { Hot } \\
\text { water }\end{array}$ & Acetone & Hexane & $\begin{array}{c}\text { Hot } \\
\text { water }\end{array}$ \\
\hline \multirow{5}{*}{ Bacillus sp. } & 25 & 1.2 & 1.7 & 0.7 & 1.2 & 0.2 & 0.9 & 0.8 & 1.0 & 0.5 \\
\hline & 50 & 1.6 & 2.0 & 0.9 & 2.1 & 0.5 & 1.0 & 0.9 & 1.1 & 0.8 \\
\hline & 75 & 1.8 & 2.2 & 1.1 & 2.2 & 0.8 & 1.0 & 1.0 & 2.1 & 1.0 \\
\hline & 100 & 1.9 & 2.1 & 1.5 & 2.0 & 1.1 & 1.1 & 1.0 & 2.0 & 1.1 \\
\hline & 125 & 1.9 & 2.3 & 1.6 & 2.1 & 1.0 & 1.3 & 1.3 & 2.2 & 1.2 \\
\hline \multirow{5}{*}{ Proteus sp. } & 25 & 1.1 & 1.5 & 1.0 & 1.3 & 0.5 & 1.1 & 1.2 & 1.0 & 1.0 \\
\hline & 50 & 1.3 & 1.7 & 1.3 & 1.5 & 0.5 & 1.2 & 1.3 & 1.1 & 1.0 \\
\hline & 75 & 1.5 & 1.8 & 1.4 & 1.6 & 0.9 & 1.2 & 1.5 & 1.5 & 1.1 \\
\hline & 100 & 1.4 & 1.8 & 1.4 & 1.6 & 1.0 & 1.3 & 1.8 & 1.7 & 1.3 \\
\hline & 125 & 1.6 & 1.9 & 1.7 & 1.8 & 1.1 & 1.2 & 1.9 & 1.8 & 1.3 \\
\hline \multirow{5}{*}{$\begin{array}{c}\text { Staphylococcus } \\
\text { aureus }\end{array}$} & 25 & 1.0 & 1.4 & 1.2 & 1.6 & 0.5 & 1.2 & 1.2 & 1.6 & 1.0 \\
\hline & 50 & 1.2 & 1.6 & 1.4 & 1.9 & 0.7 & 1.4 & 1.3 & 1.9 & $\begin{array}{l}1.1 \\
\end{array}$ \\
\hline & 75 & 1.3 & 1.7 & 1.5 & 1.8 & 1.2 & 1.3 & 1.5 & 1.7 & 1.2 \\
\hline & 100 & 1.7 & 2.1 & 1.6 & 2.0 & 1.3 & 1.5 & 1.8 & 2.1 & 1.2 \\
\hline & 125 & 1.6 & 2.2 & 1.8 & 2.1 & 1.3 & 1.6 & 1.9 & 2.2 & 1.5 \\
\hline
\end{tabular}

Table 3: The antimicrobial activity of $P$. florida, $P$. pulmonarius and $S$. commune

\begin{tabular}{|c|c|c|c|c|c|c|c|c|c|c|}
\hline \multirow[t]{3}{*}{ Test organism } & \multirow{3}{*}{ Concentration $(\mu \mathrm{l})$} & \multicolumn{9}{|c|}{ Zone of inhibition diameter $(\mathrm{cm})$} \\
\hline & & \multicolumn{3}{|c|}{ Pleurotus florida } & \multicolumn{3}{|c|}{ Pleurotus pulmonarius } & \multicolumn{3}{|c|}{ Schizophyllum commune } \\
\hline & & Acetone & Hexane & $\begin{array}{c}\text { Hot } \\
\text { water }\end{array}$ & Acetone & Hexane & $\begin{array}{c}\text { Hot } \\
\text { water }\end{array}$ & Acetone & Hexane & $\begin{array}{c}\text { Hot } \\
\text { water }\end{array}$ \\
\hline \multirow{5}{*}{ Bacillus sp. } & 25 & 1.1 & 1.5 & 1.0 & 1.2 & 1.8 & 1.0 & 1.4 & 1.0 & 0.5 \\
\hline & 50 & 1.4 & 1.6 & 1.1 & 1.8 & 2.1 & 1.3 & 1.8 & 1.5 & 0.7 \\
\hline & 75 & 1.4 & 1.4 & 1.3 & 1.8 & 2.2 & 1.3 & 1.7 & 1.7 & 1.0 \\
\hline & 100 & 1.8 & 2.0 & 1.3 & 1.9 & 2.5 & 1.5 & 1.9 & 1.8 & 1.2 \\
\hline & 125 & 1.9 & 2.2 & 1.8 & 2.0 & 2.3 & 1.8 & 2.2 & 2.0 & 1.5 \\
\hline \multirow{5}{*}{ Proteus sp. } & 25 & 1.1 & 1.3 & 0.8 & 1.0 & 1.2 & 0.9 & 1.3 & 1.1 & 1.2 \\
\hline & 50 & 1.3 & 1.5 & 1.0 & 1.2 & 1.8 & 1.1 & 1.7 & 1.4 & 1.4 \\
\hline & 75 & 1.4 & 1.6 & 1.3 & 1.3 & 1.9 & 1.3 & 1.9 & 1.4 & 1.5 \\
\hline & 100 & 1.4 & 1.8 & 1.4 & 1.7 & 2.2 & 1.4 & 2.0 & 1.6 & 1.8 \\
\hline & 125 & 1.5 & 1.8 & 1.7 & 1.8 & 2.2 & 1.7 & 1.9 & 1.7 & 1.7 \\
\hline \multirow{5}{*}{$\begin{array}{c}\text { Staphylococcus } \\
\text { aureus }\end{array}$} & 25 & 1.1 & 1.6 & 0.9 & 1.4 & 1.8 & 1.0 & 1.1 & 0.9 & 0.7 \\
\hline & 50 & 1.6 & 1.7 & 1.2 & 1.5 & 1.8 & 1.1 & 1.5 & 0.8 & 1.2 \\
\hline & 75 & 1.8 & 1.9 & 1.6 & 1.7 & 2.0 & 1.2 & 1.9 & 1.2 & 1.2 \\
\hline & 100 & 2.0 & 2.2 & 1.9 & 1.7 & 2.1 & 1.2 & 2.1 & 1.3 & 1.5 \\
\hline & 125 & 2.1 & 2.3 & 1.9 & 1.8 & 2.3 & 1.5 & 2.2 & 1.8 & 1.6 \\
\hline
\end{tabular}

Lipid oxidation of cow blood erythrocytes membrane mediated by hydrogen peroxide induces membrane damage and subsequent haemolysis. The result of the evaluation revealed that hexane extract of Pleurotus pulmonarius has high significant efficiency in inhibiting radical induced red blood cell haemolysis with $97.39 \%$.

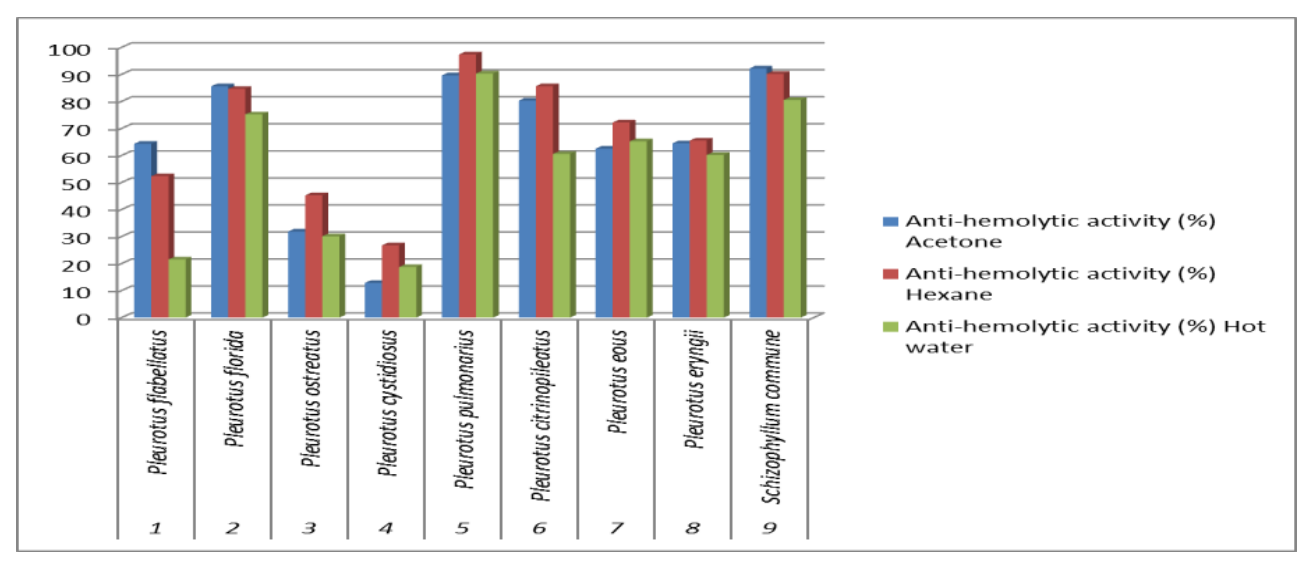

Figure 1: Anti-hemolytic activity of selected mushroom fungi 


\section{CONCLUSION}

The significant pharmacological effects and physiological properties of mushrooms are bio regulation (immune enhancement), maintenance of homeostasis and regulation of biorhythm, cure of various diseases and prevention and improvement from life threatening diseases such as cancer, cerebral stroke and heart diseases. Haemolyses has a long history of use in measuring free radical damage and its inhibition by antioxidants but only few studies have been performed with erythrocytes in whole blood. In this study, use of biological test based on free radical induced erythrocytes lysis in cow blood was performed. Lipid oxidation of cow blood erythrocytes membrane mediated by $\mathrm{H}_{2} \mathrm{O}_{2}$ induced membrane damage and subsequently haemolysis. A high significant efficiency in inhibiting radical induced red blood cell haemolyses was observed for that the hexane extract of Pleurotus pulmonarius. Edible Basidiomycetes mushroom fungi which taken for our investigation were act as a non-antibiotic alternative for preventing many bacterial diseases. Meanwhile all the extracts showed effective antimicrobial activities among which the hexane extract of Pleurotus pulmonarius showed high significant antimicrobial activity. Using these edible Basidiomycetes mushroom fungi leads to reducing amount of antibiotics prescribed for treatment of bacterial diseases and preventing drug resistance. This study demonstrated that the extracts of edible Basidiomycetes mushroom fungi act as a modern medicine for bacterial diseases. The advanced pharmacological screening of these edible plants using the modern tool may leads to some new drug.

\section{Conflicts of Interest: Nil}

\section{REFERENCES}

1. Lakhanpal TN, Rana M, Medicinal and nutraceutical genetic resources of mushrooms, Plant Genetic Resources: Characterization and Utilization, 2005; 3:288-303.

2. Jones S, Janardhanan KK, Antioxidant and antitumor activity of Ganoderma lucidum (Cart. Fr.) P.Karst.-Reishi (Aphyllophoromycetidae) from South India, International Journal of Medicinal Mushroom, 2000; 2:195-200.
3. Agahar Murugkar D, Subbulakshmi G. Nutritional value of edible wild mushrooms collected from the Khasi hills of Meghalaya, Food Chemistry, 2005; 89:599-603.

4. Boa E, Wild Edible Fungi, A Global Overview of Their Use and Importance to People, Non-wood Forest Products Series no. 17, FAO, Rome, 2004; 147.

5. Karwa A, Rai M, Mycoenhancing the potential of synthetic antibiotics using wild mushrooms: First report. Proc. $5^{\text {th }}$ Int. Medicinal Mushroom Conference, Mycological Society of China, Nantong, China, 2009; 167-172.

6. Breene $\mathrm{W}$, Nutritional and medical value of speciality mushrooms, Journal of Food Products Marketing, 1990; 53:883-894

7. Chihara G, Immunopharmacology of lentinan, a polysaccharide isolated from Lentinus edodes: its application as a host defense potentiator, International Jouranl of Oriental Medicince, 1992; 17:57-77.

8. Ooi VEC, Liu F, A review of pharmacological activities of mushroom polysaccharides. International Journal of Medicinal Mushrooms, 1999; 1:195-206.

9. Wasser SP, Weiss AL, Medicinal properties of substances occurring in higher Basidiomycetes mushrooms: current perspectives. International Journal of Medicinal Mushrooms, 1999, 31:31-62.

10. Biswas G, Sarkar S, Acharya K, Free radical scavenging and antiinflammatory activities of the extracts of Astraeus hygrometricus (Pers.) Morg., Latin American Journal of Pharmacy, 2010; 29(4):549-553.

11. Samorini G, Fungi Hallucinogeni. Studi etnomicologici. Telesterion. Dozza Ed., Bologna, Italy, Shen (Guo J, Cheng HY, Wei X. eds.), 2001; 250.

12. Gunde-Cimmerman N, Freidrich J, Cimmerman A, Benicki N, Screening fungi for the production of an inhibitor of HMG CoA reductase, production of mevinolin by the fungi of the genus Pleurotus, FEMS Microbiology Letters, 1993; 111:203-206.

13. Gunde-Cimmerman N, Medicinal value of the genus Pleurotus (Fr.) P. Kaest. (Agaricales S.l., Basidiomycetes), International Journal of Medicinal Mushrooms, 1999; 1:69-80.

14. Wasser SP, Medicinal mushrooms as source of antitumor and immunomodulating polysaccharides, Applied Microbiology and Biotechnology, 2002; 60: 258-274.

15. Chang ST, Global impact edible and medicinal mushrooms on human welfare in the $21^{\text {st }}$ century: Non green evolution, International Journal of Medicinal Mushrooms, 1999; 1:1-7. 